\title{
The tectonic evolution of the Neoproterozoic Brasília Belt, central Brazil: a geochronological and isotopic approach
}

\author{
A evolução tectônica da Faixa Brasília, Brasil central: \\ uma abordagem geocronológica e isotópica
}

\section{Márcio Martins Pimentel ${ }^{1 *}$}

\begin{abstract}
The Brasília Belt is one of the most complete Neoproterozoic orogens in western Gondwana. Rapid progress on the understanding of the tectonic evolution of the belt was achieved due to new $\mathrm{U}-\mathrm{Pb}$ data, combined with $\mathrm{Sm}-\mathrm{Nd}$ and $\mathrm{Lu}-\mathrm{Hf}$ analyses. The evolution of the Brasília orogen happened over a long period of time $(900-600 \mathrm{Ma})$ involving subduction, magmatism and terrain accretion, as a result of the consumption of the Goiás oceanic lithosphere. Provenance studies, based on U-Pb zircon data, indicate that the sedimentary rock units record different tectonic settings and stages of the evolution of the orogen. The Paranoá and Canastra groups represent passive margin sequences derived from the erosion of the São Francisco Craton. The Araxá and Ibiá groups, however, have dominant Neoproterozoic detrital zircon populations, as young as $650 \mathrm{Ma}$, suggesting derivation from the Goiás Magmatic Arc. The Goiás Magmatic Arc represents a composite arc terrain, formed by the accretion of older (ca. $0.9-0.8 \mathrm{Ga}$ ) intraoceanic island $\operatorname{arc}(\mathrm{s})$, followed by more evolved continental arcs. It extends for several thousand kilometers, from SW Goiás, through NE Brazil and into Africa. Metamorphism took place between 650 - 630 Ma reflecting final closure of the Goiás Ocean and continental collision.
\end{abstract}

KEYWORDS: Brasília Belt; Neoproterozoic; U-Pb geochronology; Sediment provenance.
RESUMO: A Faixa Brasilia é um dos mais completos orógenos Neoproterozoicos no Gondwana Ocidental. Durante os últimos dez anos, o rápido progresso no entendimento da evolução tectônica desse orógeno foi proporcionado pela produção de novos dados geocronológicos U-Pb SHRIMP e LA-ICPMS, combinados com análises Sm-Nd e Lu-Hf. Os dados demonstraram que a evoluçáo da Faixa Brasilia acontenceu ao longo de um prolongado intervalo de tempo $(900-600 \mathrm{Ma})$, envolvendo subducção, atividade ígnea e acreção de terrenos, como resultado do consumo da litosfera do oceano Goiás. Estudos de proveniência de sedimentos baseados em geocronologia U-Pb de minerais detriticos indicam que as unidades sedimentares da Faixa Brasília também registram diferentes ambientes tectônicos e estágios de evolução da Faixa. Os grupos Paranoá e Canastra representam sequências de margem passiva, derivadas da erosão do Craton do São Francisco. Por outro lado, as rochas sedimentares dos grupos Araxá e Ibiá contêm uma grande quantidade de zircóes detríticos neoproterozoicos, tão jovens quanto $650 \mathrm{Ma}$, sugerindo proveniência a partir do Arco Magmático de Goiás. Os dados geocronológicos disponiveis até o momento demonstram que o Arco Magmático de Goiás, na porção oeste do orógeno, representa um terreno de arco formado pela acreção de arcos de ilha intraoceânicos mais antigos (ca. $0.9-0.8 \mathrm{Ga}$ ), seguida do desenvolvimento de arcos continentais mais evoluidos. $O$ arco magmático se extende por alguns milhares de quilômetros na direção NNE, desde o sudoeste de Goiás, através do Nordeste brasileiro, se prolongando para o continente africano. Idades de metamorfismo, muito embora não muito abundantes, indicam pico do metamorfismo entre 650 - $630 \mathrm{Ma}$, o que provavelmente corresponde à época de fechamento do oceano e colisão continental.

PALAVRAS-CHAVE: Faixa Brasilia; Neoproterozoico; Geocronologia U-Pb; Proveniência de sedimentos.

${ }^{1}$ Institute of Geosciences, Universidade de Brasília, Brasília (DF), Brazil. E-mail:marcio@unb.br

*Corresponding author.

Manuscript ID: 20150004. Received in: 06/03/2015. Approved in: 11/27/2015. 


\section{INTRODUCTION}

The Brasília Belt, in central Brazil, is one of the most complete and complex Neoproterozoic orogens in western Gondwana. It formed during the convergence of the Amazonian, São Francisco-Congo, Paranapanema (Rio de La Plata), as well as smaller allochthonous blocks (Fig. 1). It is part of a wide and long orogenic system extending for thousands of kilometers in central and northern Brazil and in NW Africa, in the HoggarPharusian and Dahomey belts. In Brazil, this orogenic area is known as the Tocantins Province, which includes the Brasília Belt, developed along the western margin of the São Francisco Craton, as well as the Araguaia and Paraguay belts, formed along the continental margin of the Amazonian paleocontinent. They are all part of the amalgamation of West Gondwana during the neoproterozoic and eocambrian.

Over the last ten years, a considerable amount of new $\mathrm{U}-\mathrm{Pb}$ and $\mathrm{Sm}-\mathrm{Nd}$ geochronological data has been instrumental to understand in greater detail the tectonic evolution of the Brasília Belt. It has been suggested in the literature that the tectonic elements and geochronological data for the Brasília Belt record a long and complex history of deformation, metamorphism and accretion of terranes, including island arc terranes, an ophiolitic mélange, high-grade terrains and a supracrustal fold-and-thrust belt, consisting of juxtaposed metasedimentary sequences of various ages and natures (for recent reviews see Pimentel et al. 2011, Araujo et al. 2014, Cordani et al. 2013a, 2013b, Brito Neves et al. 2014, Brito Neves \& Fuck 2014).

In the present study, the tectonic evolution of the Brasília Belt was discussed mainly on the light of ID-TIMS, ion microprobe and LA-ICPMS U-Pb geochronological data published mostly over the last ten years. Some key tectonic units will be highlighted:

the supracrustal sequences of the fold-and-thrust belt and cratonic cover,

the neoproterozoic high-grade terrains (Uruaçu and Anápolis-Itauçu complexes),

- three large Neoproterozoic mafic-ultramafic complexes of Barro Alto, Niquelândia and Canabrava, and associated volcano-sedimentary sequences of uncertain age, the Goiás Magmatic Arc.

\section{GEOLOGY AND GEOCHRONOLOGY OF THE BRASÍLIA BELT}

\section{Goiás Archaean Block}

This is considered to be an allochthonous microplate, accreted to the western margin of the Brasília Belt during the latest stages of evolution of the Neoproterozoic orogen (Jost et al. 2013). It underlies an area of about $18,000 \mathrm{~km}^{2}$ (Fig. 2) and consists of typical Archean TTG granite-gneiss complexes (Queiroz et al. 2008, Jost et al. 2013), and narrow greenstone belt sequences (Fortes et al. 1995, Tassinari et al. 2006, Santos et al. 2008, Jost et al. 2010). The granite-gneiss terrains comprise orthogneisses which, in the northern portion of the terrain, comprise the Anta, Caiamar, Moquém and Hidrolina, and, in the south, the Caiçara and Uvá complexes. The metaplutonic rocks have $\mathrm{U}-\mathrm{Pb}$ ages ranging between ca. 3.04 and $2.71 \mathrm{Ga}$ and a few Sm-Nd isotopic data obtained by Pimentel et al. (2003) from samples of the southern Uvá and Caiçara complexes yielded whole-rock model ages of ca. 3.0 Ga. The U-Pb discordias presented by Queiroz et al. (2008) show patterns indicating strong Neoproterozoic Pb loss.

The greenstone belts successions are made of a basal ultramafic unit made of komatiites, locally presenting well-preserved spinifex textures and pillow structures, covered by a metabasalt unit with intercalations of chemical and pelitic metasediments. At the top, a detrital unit made dominantly of conglomerate, quartzite, metapelite and local marble is recognized. The ages of the komatiite-bearing lower units are still poorly constrained. One whole-rock $\mathrm{Sm}-\mathrm{Nd}$ isochron for komatiitic rocks of the Crixás greenstone belt yielded the age of ca. 3.0 Ga (Fortes et al. 1995). However, the provenance study of the upper metasedimentary sequences of the belts revealed the presence of Paleoproterozoic detrital zircon grains, suggesting that these upper sequences and the associated gold deposits are not part of the Archaean geology of the greenstone belts (Jost et al. 2010).

Additionaly, a few Neoproterozoic granite intrusions have been identified within the TTG terrains. One of them, in the southern part of the terrain, was dated at ca. $625 \mathrm{Ma}$, suggesting that the allochthonous Archaean block had already docked at the western margin of the Brasília Belt at that time (Pimentel et al. 2003).

\section{Exposures of Paleoproterozoic sialic basement}

Paleoproterozoic sialic basement of the Brasília Belt is exposed either as small exposures in between younger rock units or as the large siderian/rhyacian region in the northern part of the belt, known as the Natividade-Cavalcante crustal block (Fig. 3) (Fuck et al. 2014). This consists mainly of volcano-sedimentary sequences (e.g. Almas-Dianópolis) and a great diversity of orthogneisses and granitic intrusions which have been dated between 2.4 and 2.04 Ga (Cruz \& Kuyumjian 1998, Botelho et al. 2006, Fuck et al. 2013). Most of these granitoid rocks are juvenile although some of them present $\mathrm{Nd}$ models ages which are substantially older than 


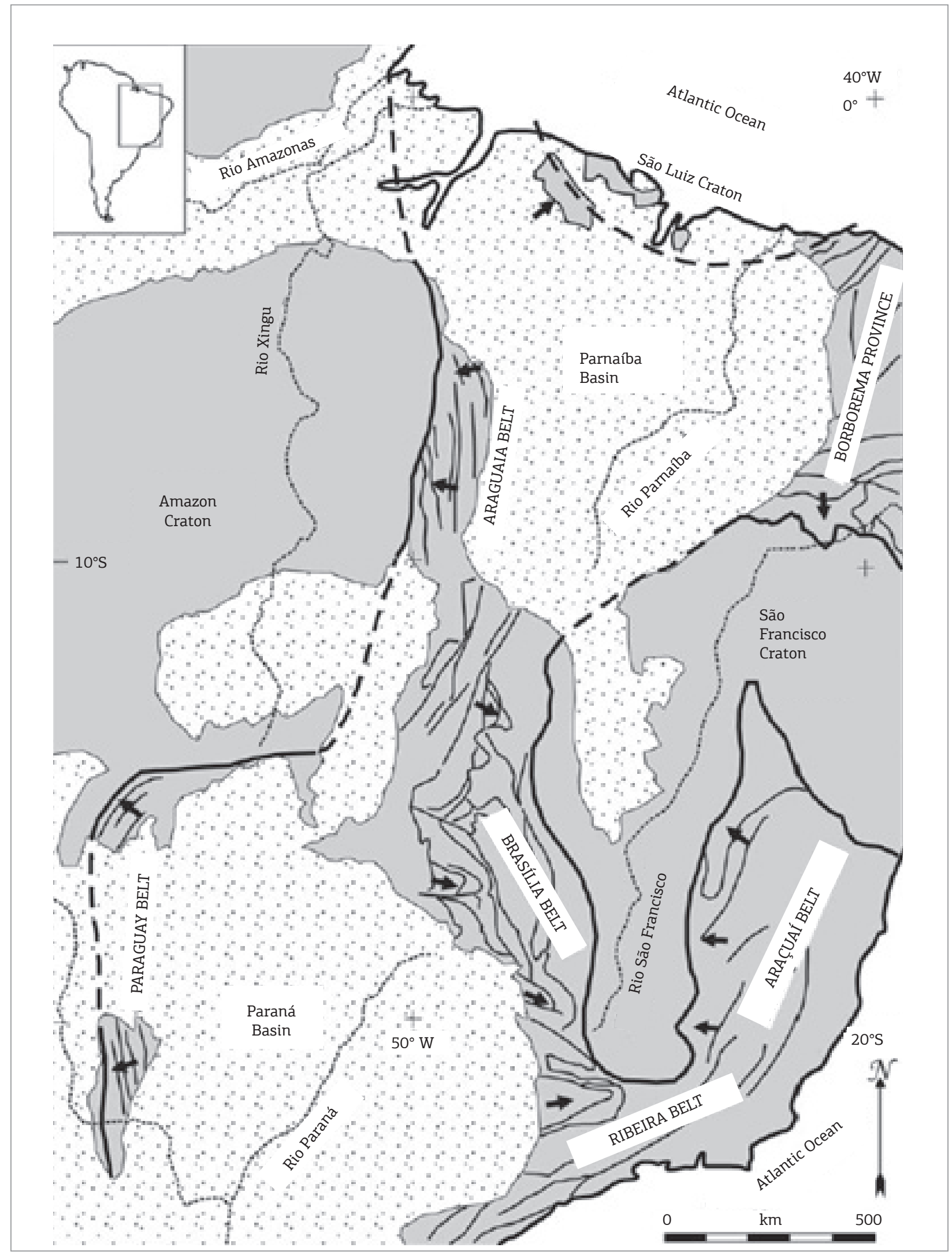

Figure 1. The tectonic elements of central Brazil, from Valeriano et al. (2012). 


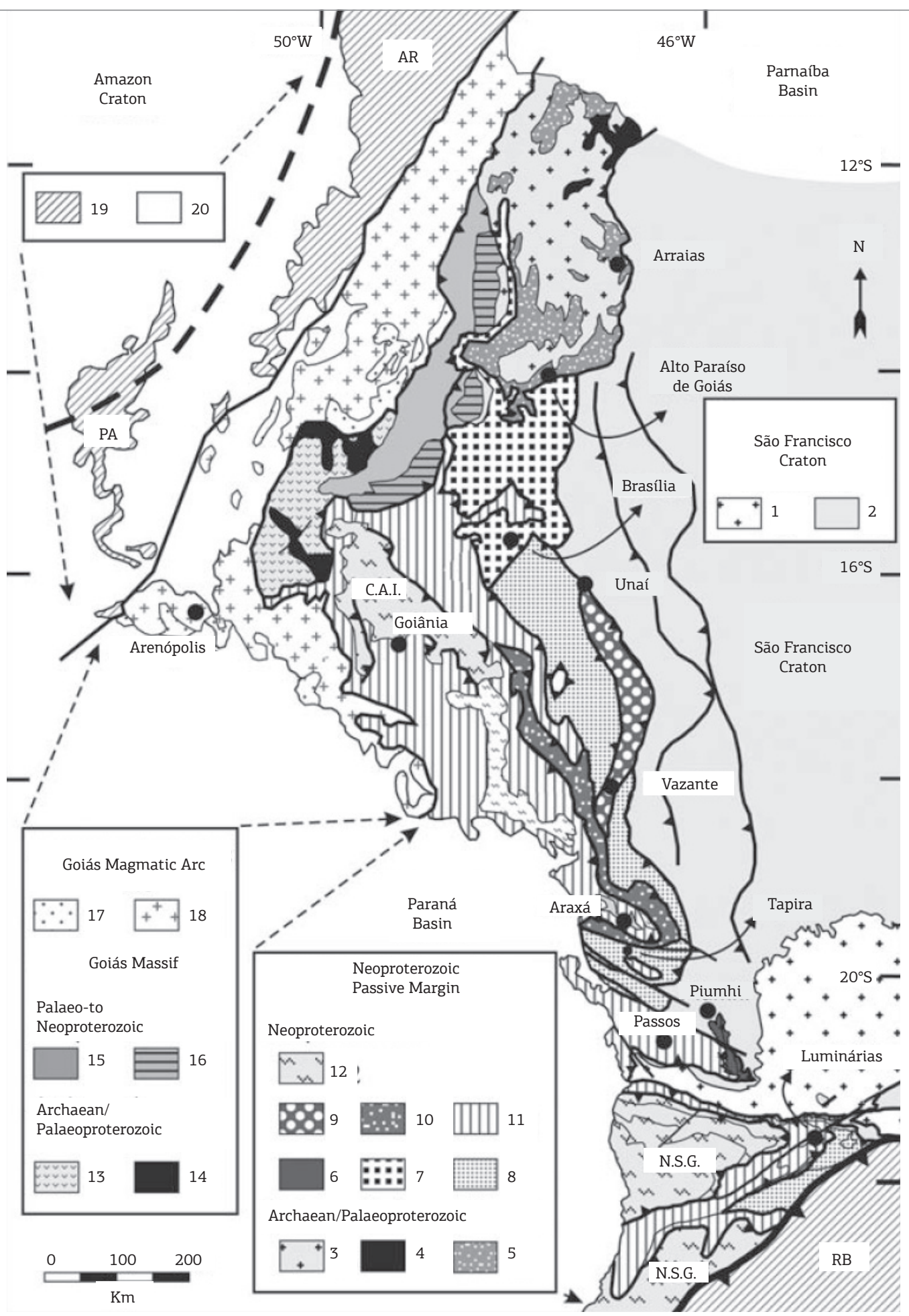

Foreland zone (São Francisco Craton): 1 - Archaean/Paleoproterozoic granite-greenstone and gneiss-migmatite terrain; 2 - Autochthonous/ Para-authocthonous metasedimentary cover (S. João del Rei, Carandaí, Andrelândia, Bambuí groups. Brasília Belt (external zone): 3 and 4 Granite-greenstone terrains; 5 - Paleoproterozoic rift (Araí Group); 6 - Ilicínea-Piumhi thrust system. Passive margin: 7 - Paranoá Group; 8 Quartzite-phyllite units (Canastra, Andrelândia groups), 9 - Vazante Group; 10 - Ibiá Group. Internal zone: 11- Araxá and Andrelândia groups; 12 - Granulite nappes; 13 and 14 - Archaean/Paleoproterozoic gneiss and greenstone complexes; 15 - Mesoproterozoic volcano-sedimentary sequences (Juscelândia, Indaianópolis, Palmeirópolis); 16 - Mafic-ultramafic complexes. Goiás Magmatic Arc: 17 - Supracrustal sequences; 18 Orthogneisses and granitoids; 19 - Paraguay (PA), Araguaia (AR) and Ribeira (RB) belts; 20 - Phanerozoic cover. From Valeriano et al. (2012).

Figure 2. The Brasília Belt (from Dardenne 2000, Pimentel et al. 2000b, Valeriano et al. 2004). 


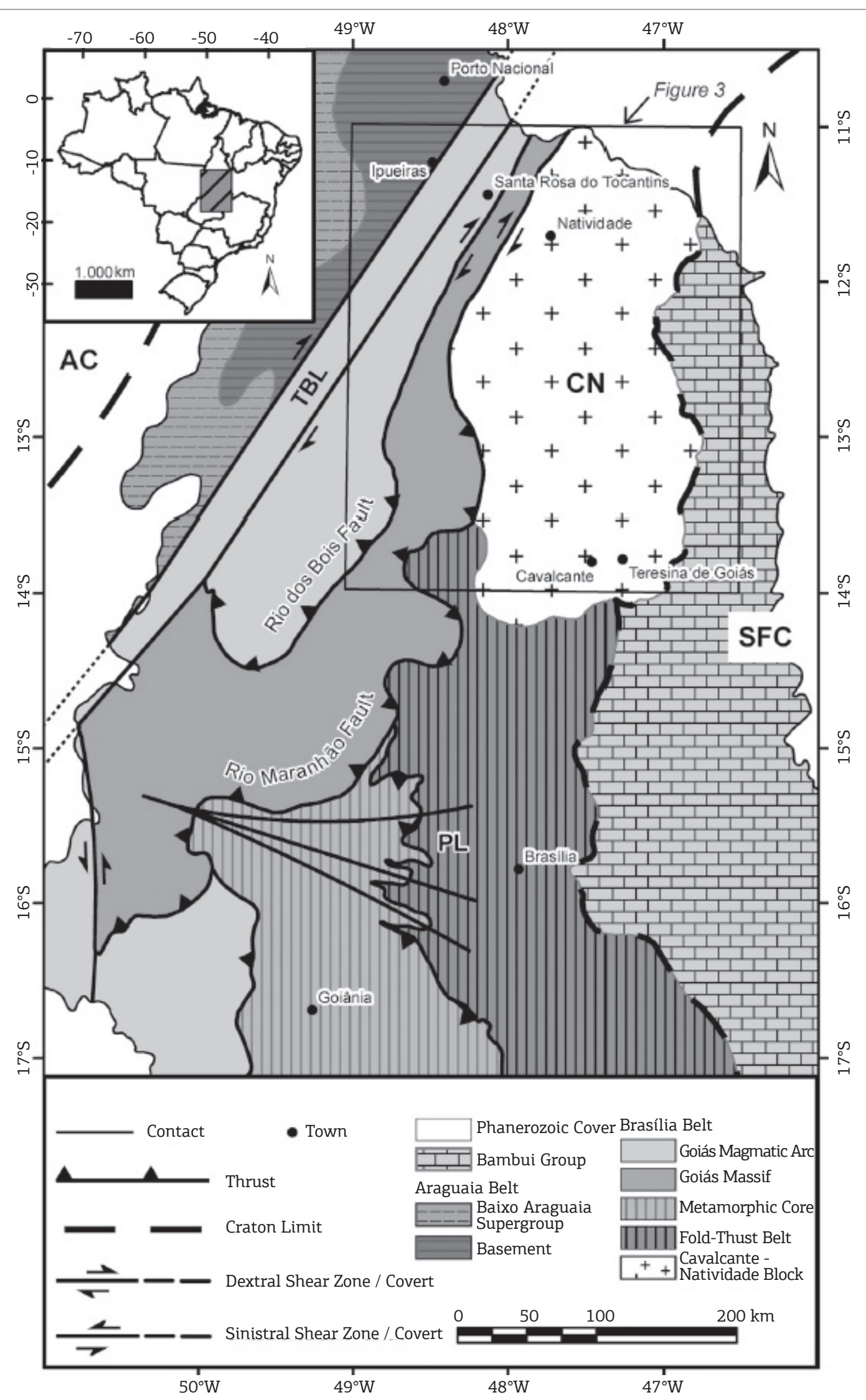

SFC: São Francisco Craton; CN: Cavalcante-Natividade Block; TBL: Transbrasiliano Lineament.

Figure 3. The northern part of the Brasília Belt. 
their crystallization ages, suggesting either local reworking of Archaean sialic crust or contamination with metapelites of the Paleoproterozoic Ticunzal Formation (Fuck et al. 2013). In the south of the block, small Statherian A-type granite intrusions are exposed (ca. $1.77 \mathrm{Ga}$; Pimentel et al. 1991) coeval with the rhyolites at the base of the Araí Group rift sequence. Additionally to this large basement area in the northern part of the belt, other small Paleoproterozoic inliers are recognized in different parts of the orogen especially in its southern half. Examples are the 2.19-2.07 Ga old Campinorte Sequence (Della Giustina et al. 2009a, Cordeiro et al. 2014), the Silvânia Volcano-Sedimentary Sequence $(2.12 \mathrm{Ga})$ and the Jurubatuba granite $(2.09 \mathrm{Ga})$ (Fischel et al. 2001), which are pointed out in Fig. 2.

The regional geological and geochronological data available so far indicate that these exposures of Paleoproterozoic sialic rocks represent fragments of the continental basement of the supracrustal sequences of the Brasilia Belt, whereas the Goiás Archaean Block consists of an allochthonous terrain accreted to the margin of the orogen at the end of the Neoproterozoic. This is supported by the gravity data provided by Marangoni et al. (1995), which reveals an important gravimetric discontinuity separating the supracrustal rocks of the Brasília Belt in the east from the Goiás Magmatic Arc, Goiás Archaean Block and the three large mafic-ultramafic complexes to the west (ca. $790 \mathrm{Ma}$ old Barro Alto, Niquelândia and Canabrava complexes, from north to south).

\section{The metasedimentary sequences: provenance and age of the Paranoá, Canastra, Ibiá, Araxá and Bambuí Groups}

The age and significance of the different sedimentary rock units of the Brasilia Belt have been a question of continuous debate. They form a thick pile of sedimentary units extending for more than $1,000 \mathrm{~km}$ roughly in the NS direction, along the western margin of the Saao Francisco Craton (Figs. 1 and 2). Regional, west-dipping thrusts, reverse faults and nappes mark the limits between the main stratigraphic units and clearly indicate tectonic transport towards the east (for a review see Valeriano et al. 2012). Traditional approaches have interpreted them as part of a passive margin sequence deposited on the continental shelf of the São Francisco paleocontinent (e.g. Marini et al. 1984). However, the strong deformation disrupted the original stratigraphic organization, and the general absence of intercalations of volcanic rocks has made difficult the exercise of reconstructing the original setting and age of the basin(s). More recently, some efforts have been carried out in order to investigate the provenance of the original sediments using mainly LA-ICPMS U-Pb analyses on detrital zircon (Pimentel et al. 2001,
Piuzana et al. 2003a, Valeriano et al. 2004, Pimentel et al. 2011, Rodrigues et al. 2010, 2012, Matteini et al. 2012). These studies have provided useful information on the maximum age of deposition and on the original tectonic setting of the different supracrustal associations, in special of the Araxá, Ibiá, Canastra and Paranoá groups (for a review see Pimentel et al. 2011).

The Paranoá Group comprises a mature siliciclastic sedimentary pile including thick quartzite layers, with intercalation of metasiltstone and minor lenses of limestone and dolostone (for a review see Campos et al. 2013). It starts at the base with a paraconglomerate, followed by transgressive and regressive siliciclastic cycles, ending, at the top, with pelites and dolostones containing Conophyton metulum Kirichenko stromatolites (Cloud \& Dardenne 1973). Available geochronological and microfossil data for the Paranoá Group suggest ages between ca. 1,170 and $950 \mathrm{Ma}$ for source regions within the Sáo Francisco craton (Guimarães 1997, Pimentel et al. 2001, Matteini et al. 2012). The $50 \mathrm{~m}$-thick Sáo Miguel conglomerate represents the rift phase of the Paranoá basin. It is overlain by rhythmites with mudcracks and evaporite layers, typical of tidal environments. These are followed by marine rhythmites and quartzites deposited in a platformal environment dominated by tidal currents. The sediments in the upper portion of the Paranoá Group display features indicating more varied environments, reflecting important fluctuations of the sea level. In this section, deeper water pelites alternate with tidal rhythmites and quartzites, storm rhythmites, limestones and stromatolitic dolomites. Arkoses and quartzites at the upper part of the Paranoá sequence are chemically similar to passive margin clastic sediments (Guimarães 1997).

The Canastra Group comprises a typical platformal association of psammitic and pelitic metasediments, with some carbonatic intercalations. Phyllites and quartzites are the most common rocks. The basal part of the group (Serra do Landim Formation) is made of chlorite-rich calc-phyllite or calcschist. Towards the top, the Paracatu and the Chapada dos Pilóes formations are formed by carbonaceous phyllites and quartzites, representing a coarsening-upward sequence formed by a regressive megacycle. This is made of deep water sediments, grading into turbidites deposited on a continental slope by gravitational currents and to top platformal deposits with hummocky structures and cross stratification, indicating sediment transport from east to west. The Canastra Group is considered to be the lateral equivalent of the Paranoá Group (Dardenne 2000). The relationships between the Canastra, Araxá and Ibiá groups are not clear due to intense tectonic imbrication between these units. 
The Ibiá Group has been divided into two formations: (i) the Cubatáo Formation, at the base, lying on an erosive unconformity over the Canastra Group and consisting of a thick diamictite unit, and (ii) the Rio Verde Formation, at the top, which is made of deep water calcschists and calc-phyllites with fine layers of quartzite. The Cubatâo diamictite has been correlated with the Jequitaí Diamictite, while the phyllites are considered to be equivalent to the metasediments of the Araxá Group. Geochemical features of the phyllites in the southern part of the belt indicate provenance from a primitive island arc source (Seer 1999).

The Araxá Group is dominantly made of micaceous quartzite and micaschists including calcschists, chlorite-muscovite schist, biotite-garnet schist, staurolite schist and feldspar schists, with a few paragneiss and marble intercalations. The internal stratigraphy of the group is poorly known due to intense deformation with development of low angle thrust sheets. Volcanic rocks associated with the Araxá micaschists are observed in many areas. These are amphibolites, meta-andesites and rhyolites (Pimentel \& Fuck 1992, Valeriano \& Simóes1997). In the eastern part of the Araxá Group, the ca. 0.79 Ga Maratá Sequence represents a narrow strip of rhyolitic/granitic rocks interlayered with the Araxá metasediments. This ca. $100 \mathrm{~km}$ long narrow unit was initially interpreted as volcanic (e.g. Pimentel \& Fuck 1992) and later re-interpreted as highly deformed syn-tectonic intrusions. In the latter interpretation, therefore, the U-Pb zircon age of $0.79 \mathrm{Ga}$ (Pimentel \& Fuck 1992) represents a minimum age for the deposition of the Araxá sediments. Amphibolites intercalated with the Araxá schists near Goiânia have been dated at ca. 0.8 Ga (SHRIMP U-Pb zircon data of Piuzana et al., 2003a). The trace element characteristics of these amphibolites are very similar to MORBs and they have been interpreted as slices of ocean floor tectonically emplaced within the Araxá metasediments. In summary, the stratigraphic relationships between these metaigneous rocks and the Araxá metasediments are still far from clear and remain controversial due to tectonic imbrications. Another important feature associated with the Araxá rocks is the presence of a large number of small lenses of serpentinite, amphibolite and talc schist, with podiform chromite deposits, representing a long, roughly NS ophiolitic mélange (Strieder \& Nilson 1992).

Provenance data based on U-Pb ages of detrital zircon grains of the four stratigraphic units above are summarized in Figs. 4 and 5 and reveal important differences between the sedimentary units.

The Bambuí Group is the most important Neoproterozoic sedimentary unit in central Brazil, forming the easternmost part of the Brasilia Belt and covering large areas of the São Francisco Craton. Its basal diamictite (Jequitaí Formation) sits

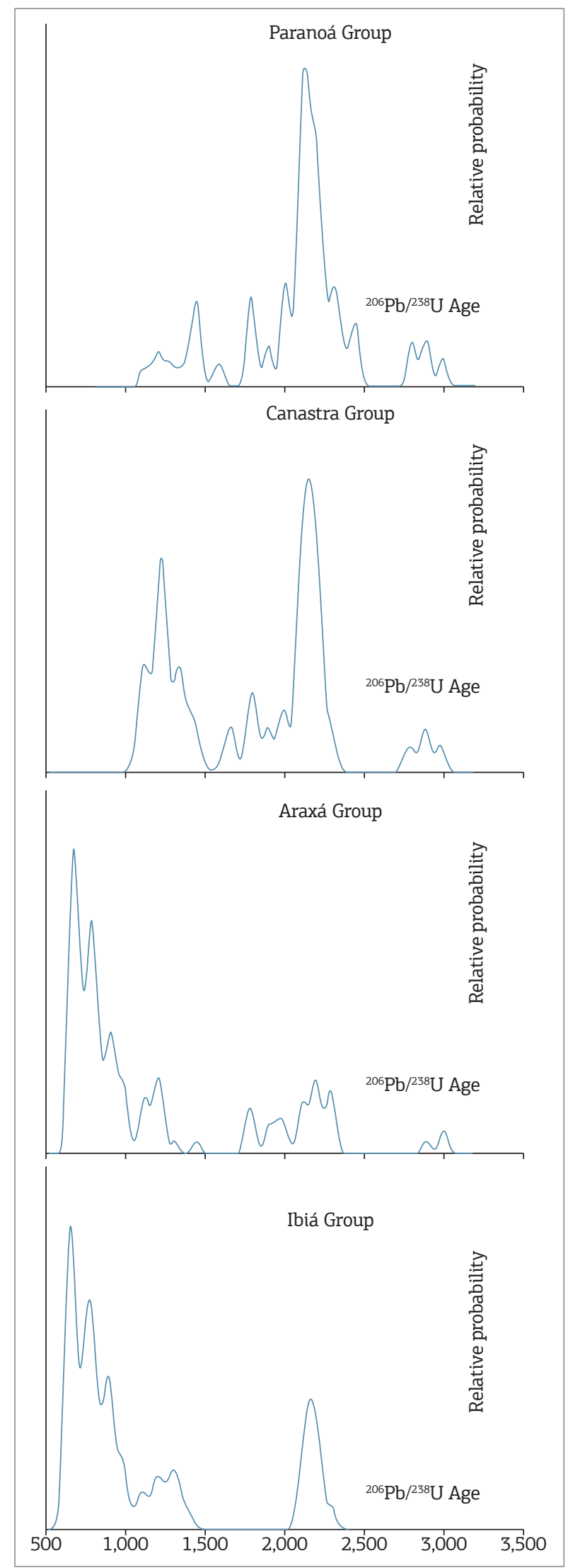

Figure 4. Provenance patterns of metasedimentary units of the Brasília Belt. 
unconformably on the Paranoá Group. The age of this glacial event remains controversial. The end of this glaciation was followed by the development of a marine environment and the onset of deposition of the pelitic-carbonatic sediments of the base of the Bambui Group. According to Santos et al. (2000), the sediments of the Bambuí Group were deposited in an epicontinental sea influenced by tectonic movements
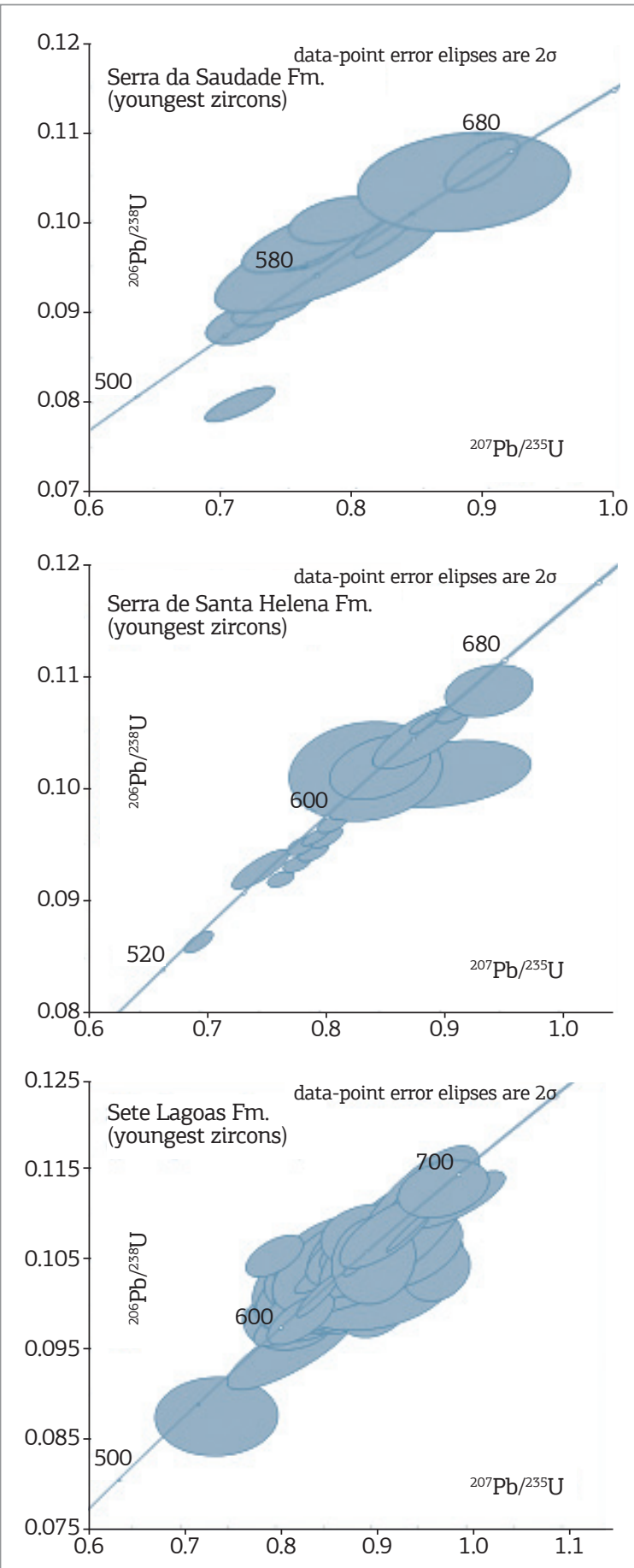

Figure 5. Concordia diagrams for detrital zircon grains of the Bambuí Group. in the Brasília Belt (Martins, Lemos 2007). The Bambuí sedimentary rocks comprise three regressive megacycles. Each of these megacycles begins with a fast marine transgression of regional amplitude, associated with a sudden subsidence of the basin evidenced by deep pelitic marine facies, passing to shallow-platform facies and tidal to supratidal facies.

The age of deposition of the Bambuí Group has been a matter of discussion for many years. $\mathrm{Sr}$ and $\mathrm{Pb}$ isotopic data reported by Parenti-Couto et al. (1981) suggested depositional ages of ca. $600 \mathrm{Ma}$. Similarly, previous $\mathrm{Rb}-\mathrm{Sr}$ and $\mathrm{K}-\mathrm{Ar}$ data on shales reported by Thomaz Filho et al. (1998) have produced ages between ca. $640 \mathrm{Ma}$ for the basal Sete Lagoas Formation and $540 \mathrm{Ma}$ for the Três Marias Formation at the top of the succession. More recently, the cap dolostones at the base of the Sete Lagoas overlying Jequitaí diamictites have been dated at ca $740 \mathrm{Ma}(\mathrm{Pb}-\mathrm{Pb}$ isochron; Babinski et al., 2007). The data, associated with $\mathrm{C}$ and $\mathrm{Sr}$ isotopic data for the carbonates support a Sturtian age for the Jequitaí glaciation. However, the provenance age presented by Rodrigues (2008) and Pimentel et al. (2011), for the basal Sete Lagoas, Serra de Santa Helena, as well as for the Serra da Saudade formations, revealed the presence of a large amount of late Neoproterozoic zircons, dated at ca. $600 \mathrm{Ma}$ and even a few grains being as young as $550 \mathrm{Ma}$ (Fig. 5). This suggests a very late Neoproterozoic or even early Cambrian age for the deposition of the Bambuí Group as equally indicated by the data presented by Paula-Santos et al. (in press) for the basal Sete Lagoas Formation. This is supported by the recent discovery of Ediacara fauna in carbonates of the Sete Lagoas Formation (Warren et al. 2014).

According to the model by which some of these sedimentary rock units (in special the Paranoá, Canastra, Araxá and Ibiá groups) represented the passive margin of the São Francisco Craton, the original sediments should display provenance patterns dominated by Paleoproterozoic and Archaean zircons, with subordinate mesoproterozoic grains. The results demonstrated, however, that this is not the case. A compilation of the provenance data produced by the studies above is shown in Fig. 4. Siliciclastic rocks of the Paranoá and Canastra groups show provenance ages which are compatible with erosion of source regions within the São Francisco Craton, with predominance of Paleoproterozoic detrital zircons. On the other hand, the pelitic and psammitic rocks of the Araxá and Ibiá Groups display very distinct provenance patterns with a large amount of Neoproterozoic zircon grains, as young as $640 \mathrm{Ma}$. A younger source is, therefore, required.

\section{The Goiás Magmatic Arc}

The Goiás Magmatic Arc is one of the most important tectonic units of the Brasília Belt and represents one of the most of expressive episodes of juvenile crustal accretion 
during the assembly of Gondwana. It is exposed in two main areas, separated by Goiás Archean Block. The southern portion of the Arc is known as the Arenópolis Arc, and the northern, as the Mara Rosa Arc, extending for hundreds of kilometers in the NNE direction (Fig. 2). In both areas, the arc started its evolution at ca. $900 \mathrm{Ma}$ in intraoceanic island arcs (Pimentel \& Fuck 1992), and the final widespread magmatic event took place between ca. 630 - 600 $\mathrm{Ma}$, during closure of the Goiás-Pharusian Ocean (Cordani et al. 2013a). The Goiás magmatic arc is formed by:

- supracrustal sequences comprising calc-alkaline metavolcanic rocks, feldspar-bearing micaschist and minor quartzite and marble (e.g. the Santa Terezinha, Mara Rosa and Arenópolis sequences), and

- calc-alkaline plutonic rock units variably deformed and metamorphosed, ranging in composition from gabbro to granite, with a large volume of tonalites (Arantes et al. 1991). The rock units above were intruded by large, bimodal, post-tectonic granite intrusion.

The orthogneisses are mostly hornblende-bearing metadiorites, metatonalites and metagranodiorites. The rocks display positive $\varepsilon_{\mathrm{Nd}}(\mathrm{T})$ values and $\mathrm{Nd}$ model ages mostly between 0.8 and 1.1 Ga (Pimentel et al. 1991, 1997, 2000a, Pimentel \& Fuck 1992). Geochemical and isotopic data suggest that some of the original tonalitic/andesitic magmas were similar to modern adakites (Pimentel et al. 1991, Pimentel et al. 1997). U-Pb zircon ages indicate the igneous protholits crystallized in three main events:

1. The oldest igneous events happened between ca. 900 and $804 \mathrm{Ma}$, and are represented by the juvenile Arenópolis, Sanclerlândia and Mara Rosa orthogneisses, among others (Pimentel et al. 1991, Pimentel \& Fuck 1992), the Sanclerlândia gneiss (828 - $822 \mathrm{Ma}$ ) (Laux et al. 2005); these plutonic rocks have been compared with primitive M-type granitoids of intra-oceanic island arcs; $\mathrm{Nd}$ isotopic data indicate $\mathrm{T}_{\mathrm{DM}}$ ages ranging from 0.89 to $1.2 \mathrm{Ga}$ and $\varepsilon_{\mathrm{Nd}}(\mathrm{T})$ values between +0.37 and +6.0 (Pimentel $\&$ Fuck 1992, Pimentel et al. 1996; Laux et al. 2005). In the Mara Rosa Arc, the Mutunópolis gneisses, crystallized between ca. 0.81 and 0.80 , represent a sub-group of this group, displaying conspicuous inheritance in the zircon pattern and considerably older $T_{\mathrm{DM}}$ model ages $(-2.0 \mathrm{Ga})$.

2. The second event is represented arc by peraluminous muscovite-bearing metagranitoids (e.g. the Creoulos Granite) generated between 790 and $786 \mathrm{Ma}$ and exposed in the easternmost part of the Arenópolis arc. The $\varepsilon_{\mathrm{Nd}}(\mathrm{T})$ values vary from -1.8 to +3.6 with $\mathrm{T}_{\mathrm{DM}}$ model ages in the interval between 1.46 and $1.1 \mathrm{Ga}$ (Laux et al. 2005).

3. The youngest event took place between 669 and 630 $\mathrm{Ma}$, being represented by the metaluminous Mantrixã gneiss (669 Ma) and by the Turvânia, Palminópolis and Firminópolis gneisses with $\mathrm{U}-\mathrm{Pb}$ emplacement ages between 637 and $630 \mathrm{Ma}$ (Laux et al. 2005). The $\mathrm{Nd}$ isotopic signature is varied: the Matrinxã gneiss has positive $\varepsilon_{\mathrm{Nd}}(\mathrm{T})$ of +2.2 and $\mathrm{T}_{\mathrm{DM}}$ age of $0.99 \mathrm{Ga}$, whereas the Turvânia-Palminópolis-Firminópolis gneisses have dominantly negative $\varepsilon_{\mathrm{Nd}}(\mathrm{T})$ values ranging from -15.1 to +0.3 with $\mathrm{T}_{\mathrm{DM}}$ ages between 1.1 and $2.2 \mathrm{G}$.a (Laux et al., 2005).

Late to post-tectonic bimodal intrusions intruded the rock units above both in the Arenópolis and in the Mara Rosa arcs. They range in age between ca. 0.63 and $0.54 \mathrm{Ga}$. In the Arenópolis arc, they are mainly metaluminous, high-K calc-alkaline to alkaline (A-type) granites associated with small gabbrodioritic bodies, whereas in the Mara Rosa arc peraluminous granite intrusions are also recognized (e.g. Faina and Amador granites).

The different episodes of plutonism in the Goiás Magmatic Arc can be recognized in the Mara Rosa area, as demonstrated in Figure 6; however, the young post-tectonic A-type granitic intrusions (ca. 0.54-0.52 Ga) have not been identified in Mara Rosa.

The long history of arc activity suggests successive amalgamation of magmatic arcs, either island or continental arcs, forming a long and wide composite arc terrain. It is clear now that the Goiás Magmatic Arc extends in the NNE direction underlying a large area in central Brazil. In its northern end, it is covered by the Paleo-Mesozoic sedimentary rocks of the Parnaíba Basin and similar arc rocks are also present in NW Brazil, in the state of Ceará, and in Africa in the Hoggar-Pharusian area where several neoproterozoic juvenile magmatic arcs, such as the Tilemsi and Amalaoulaou, similar to the Goiás Magmatic Arc, are

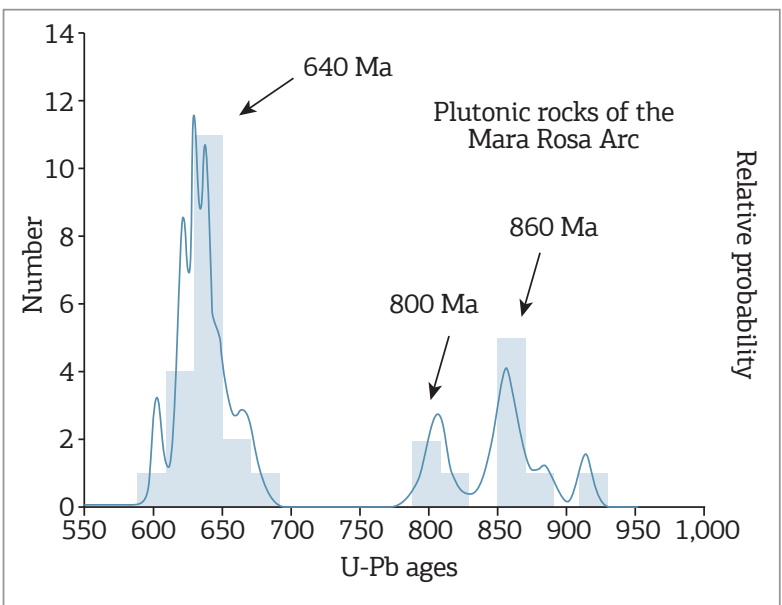

Figure 6. U-Pb ages of orthogneisses and granitoids of the Mara Rosa magmatic arc. 
recognized (Caby et al. 1989, Dostal et al. 1994, Berger et al. 2011, Caby 2003, Cordani et al. 2013a, 2013b). The arc system, therefore, formed a semi-continuous belt of neoproterozoic subduction-related complexes extending for over $5,000 \mathrm{~km}$, similar to the present-day arcs of the West Pacific Ocean.

\section{Neoproterozoic high grade terrains}

\section{Uruaçu Complex}

The Uruaçu high-grade Complex underlies a small area in the central part of the Goiás Massif (Fig. 7). It is a structurally complex terrain formed mainly by quartz

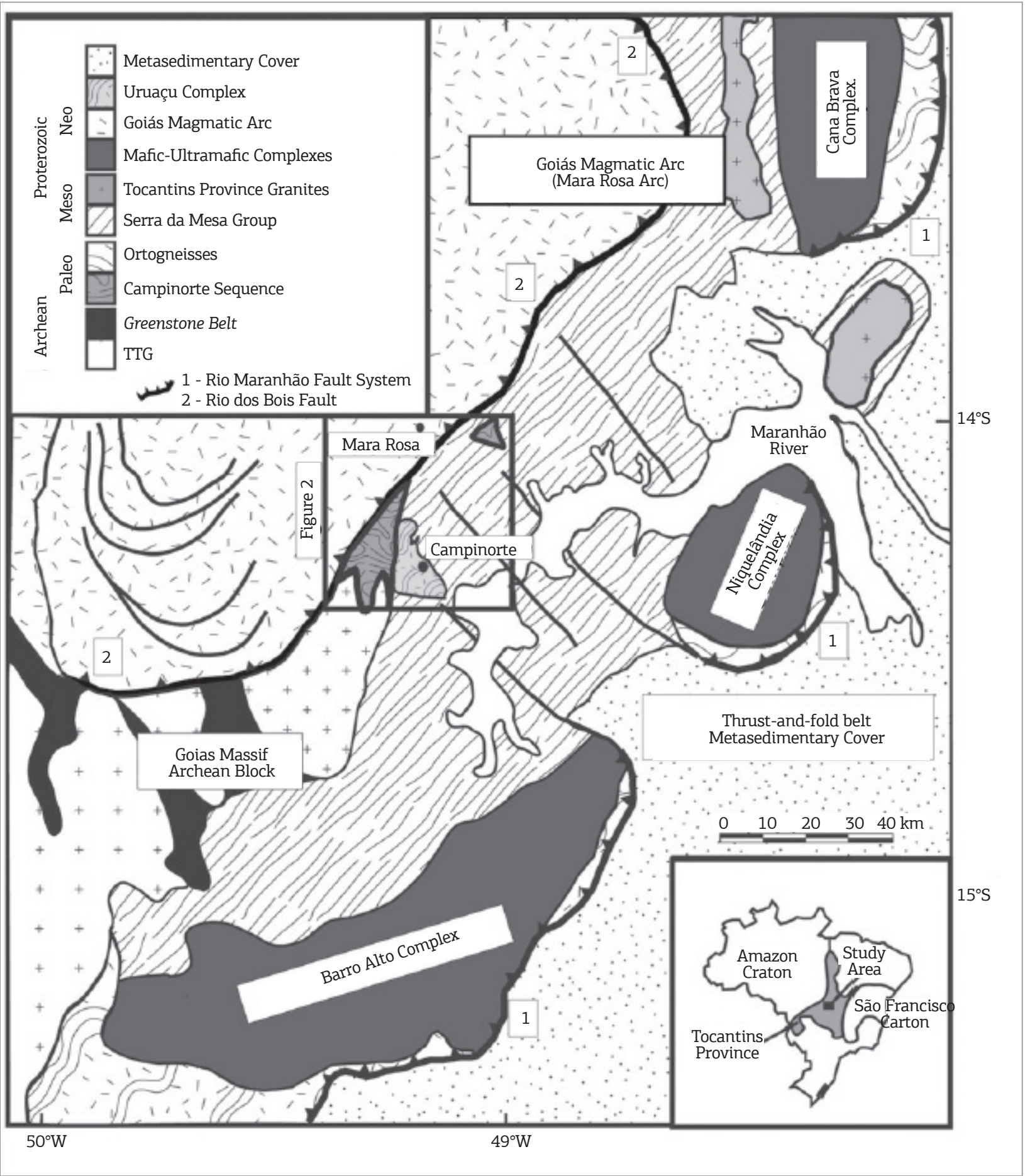

Figure 7. Location of the three large layered mafic-ultramafic complexes. 
dioritic orthogneisses and sillimanite-cordierite-bearing paragneisses.

The orthogneisses arethe dominant rock type in the Uruaçu Complex and are generally strongly deformed and migmatized. They are associated with mafic and ultramafic rocks consisting of garnet-amphibolite, and fine- to medium-grained schists, with cummingtonite, actinolite, talc, magnesite, garnet and clinochlore, arranged in a diablastic texture.

Paragneisses are medium- to coarse-grained banded granulites, with alternating sillimanite-cordierite rich layers and quartz-feldspar bands. They contain spinel and quartz, which is representative of ultrahigh-temperature metamorphism. Garnet-bearing quartz-feldspar-biotite-chlorite-muscovite rock is also common in the supracrustal association.

Recent U-Pb geochronological data indicated that orthogneisses, amphibolites and migmatites crystallized between ca. 690 and $651 \mathrm{Ma}$ (Della Giustina et al. 2009b). Therefore, magmatism and high grade metamorphism took place within this $40 \mathrm{My}$ time span. Detrital zircon grains for one paragneiss sample have a simple provenance pattern with ages mostly in the range between 760 and $800 \mathrm{Ma}$. This suggests that the original basin represented a syn-orogenic basin, younger than ca. $760 \mathrm{Ma}$, formed by the erosion of sources possibly within the Goiás Magmatic Arc.

\section{Anápolis-Itauçu Complex}

The Anápolis-Itauçu Complex (AIC) is exposed in the central part of the Brasília Belt. It constitutes an elongated NW-SE zone of high-grade rocks exposed between the Goiás Magmatic Arc and the lower-grade metasedimentary rocks of the Araxá Group. Geological contacts are marked by high-angle shear-zones in the northern segment of the AIC and by low-angle nappe structures in the south, thus preventing the identification of stratigraphic or cross-cutting relationships between the different rock units. Geochronological data support the interpretation that at least part of the AIC may represent high-grade equivalents of the Araxá Group (Piuzana et al. 2003b) and might be the exposure of the roots of the original mountain chain. The AIC includes a variety of rock types forming NW-oriented segment, in which three main rock associations may be recognized:

1. orthogranulites;

2. paragranulites; and

3. granite intrusions.

The orthogranulites are represented by tonalitic to granodioritic gneisses, as well as by mafic rocks, exposed either as dioritic/gabbroic intrusions or as mafic-ultramafic layered complexes made of peridotite, pyroxenite, gabbro and gabbro-anorthosite. Despite the high-grade metamorphism, relict igneous textures and compositional layering are usually observed. Geochemical data suggest a tholeiitic parental magma, with LREE enrichment and a negative Eu anomaly, and the high-Al content of relict igneous pyroxenes suggests that the intrusion took place at deep levels in the crust. Paragranulites are typically represented by aluminous granulites with variable amounts of sillimanite, garnet, spinel, cordierite and feldspar. Calc-silicate rocks and impure quartzites are also recognized. Ultrahigh temperature mineral assemblages, such as saphirine+quartz, orthopyroxene+ sillimanite +quartz, wollastonite+scapolite and hercynite+quartz, have been identified in several localities of the AIC and revealed temperatures higher than $1,100^{\circ} \mathrm{C}$, at moderate pressures ( 10 kbar; Baldwin et al. 2005; Moraes et al. 2002, 2006). Granite intrusions are also part of the AIC. They show variable deformational and metamorphic overprint, locally reaching granulite facies conditions (Piuzana et al. 2003b). Most of these granites are peraluminous, and the $\mathrm{Nd}$ isotopic signatures indicate that they may be represent product of anatexis of either the aluminous paragranulites of the AIC or metasedimentary rocks of the Araxá Group (Piuzana et al. 2003a). U-Pb zircon ages for cores and metamorphic rims are identical in some of these bodies, and, therefore, the granites are interpreted as syn-tectonic deep-crustal level intrusions (Piuzana et al. 2003a).

SHRIMP U-Pb ages of igneous zircon from orthogranulites including felsic and mafic rocks, as well as the intrusive granites, vary between 760 and $630 \mathrm{Ma}$, and metamorphic overgrowths are dated at ca. $650-640 \mathrm{Ma}$, suggesting that UHT metamorphism, emplacement of mafic magmas and anatexis were partially coeval (Piuzana et al. 2003b, Della Giustina et al. 2011). $\mathrm{T}_{\mathrm{DM}} \mathrm{Sm}-\mathrm{Nd}$ model ages of orthogranulites fall into two age intervals, between $2.3-1.9 \mathrm{Ga}$ and $1.7-1.4 \mathrm{Ga}$, and $\varepsilon_{\mathrm{Nd}}(\mathrm{T})$ values are negative, ranging from -9.3 to -1.4 (Piuzana et al. 2003a). The younger $T_{D M}$ values are in agreement with zircon inheritance pattern observed in paragranulites (2.0 to $0.8 \mathrm{Ga}$; Piuzana et al. 2003a), which indicates that the Neoproterozoic Goiás Magmatic Arc, exposed to the west, might have been one of thesedimentary sources contributing to the basin (Piuzana et al. 2003a). The data suggest that the high-grade terrains represent the metamorphic core of the Brasília orogen.

\section{The Barro Alto, Niquelândia and Canabrava Mafic-Ultramafic Layered Complexes}

Three composite Meso-Neoproterozoic layered complexes define a $300 \mathrm{~km}$ long belt along the central-northern 
part of the Brasília Belt (Fig. 6). Due to their geological and geochronological similarities, they have been interpreted as representative of an originally single regional-scale structure, which was disrupted during the Brasiliano event forming three individual bodies (Ferreira Filho et al. 1998). The three complexes consist of two magmatic systems, distinguished by their petrological and isotopic characteristics (Ferreira Filho et al. 1994, Ferreira Filho \& Pimentel 2000, Pimentel et al. 2004, Ferreira Filho et al. 2010).

The composite intrusions are known as the Canabrava, Niquelândia and Barro Alto complexes, from north to south. In addition, previous denominations for the Mesoproterozoic layered units, exposed in the southern and central intrusions, were revisited and, accordingly, they were renamed Serra da Malacacheta and Serra dos Borges complexes, respectively (Ferreira Filho $e t$ al. 2010). The ages of these two magmatic systems are still controversial. Ferreira Filho et al. (2010), Pimentel et al. (2006) and Della Giustina et al. (2011) suggest that the western part of the complexes and the associated volcano-sedimentary sequences of Juscelândia, Indaianópolis and Palmeirópolis are mesoproterozoic in age, whereas the eastern part crystallized at ca. $780 \mathrm{Ma}$.

On the other hand, Correia et al. (2012) present data for the Niquelândia Complex, suggesting that both systems are neoproterozoic. According to Ferreira Filho et al. (1994), the Mesoproterozoic intrusions $(-1.3 \mathrm{Ga})$ are composed of interlayered leucotroctolite, leucogabbro, anorthosite and occasional pyroxenite, whereas the Neoproterozoic complexes $(-0.8 \mathrm{Ga})$ consist of several cyclic units of dunite, pyroxenite and gabbronorite, within which slices of supracrustal rocks and granite intrusions metamorphosed under high grade conditions are widespread. Trace element composition and $\mathrm{Sm}-\mathrm{Nd}$ isotopic data reveal contrasting geochemical signature for both units; in the older unit, analyses attest to a depleted-mantle source for the original magmas (Ferreira Filho \& Pimentel 2000, Moraes et al. 2003), whereas the younger association shows a large degree of crustal contamination with older sialic crust (Pimentel et al. 2004, 2006, Correia et al. 2012). To the west, the three composite bodies are in contact with Mesoproterozoic bi-modal volcano-sedimentary sequences, namely the Palmeirópolis, Indaianópolis and Juscelândia sequences, from north to south. The sequences display similar stratigraphy and consist of metapelite, calc-silicate rocks and metachert interbedded with metavolcanic rocks, consisting of fine-to-medium grained amphibolite and felsic gneiss (Brod \& Jost 1991, Moraes \& Fuck 1994, 1999, Ferreira Filho et al. 1998, Moraes et al. 2003). Amphibolites of the Juscelândia and Palmeirópolis sequences show positive
$\varepsilon_{\mathrm{Nd}}$ values and trace element signatures typical of MORBlike magmas, suggesting that the volcano-sedimentary sequences represent a continental rift that evolved towards an oceanic basin (Moraes et al. 2003, 2006). The composite mafic-ultramafic complexes, with their respective volcano-sedimentary sequences, underwent amphibolite to granulite facies metamorphism, with $\mathrm{P}$ and $\mathrm{T}$ conditions increasing progressively from west to east. Locally, ultra-high-temperature mineral assemblages are observed (Moraes \& Fuck 1994, 2000, Ferreira Filho et al. 1998). SHRIMP U-Pb zircon analyses performed on metamorphic overgrowths constrain the age of the high-grade metamorphism in the composite layered intrusions at approximately 760 - $750 \mathrm{Ma}$ (Pimentel et al. 2004, 2006, Moraes et al. 2006). Additionally, rutile U-Pb ages reveal a younger metamorphic event around $610 \mathrm{Ma}$, which is interpreted as related to the uplift of the complexes at the end of the Brasiliano orogeny (Ferreira Filho et al. 1994). The current structural configuration of the three composite layered complexes (Fig. 6) is ascribed to this final tectono-metamorphic episode.

\section{DISCUSSION AND CONCLUSIONS: THE TECTONIC EVOLUTION OF THE BRASÍLIA BELT}

During the last ten years, new LA-ICPMS and SHRIMP $\mathrm{U}-\mathrm{Pb}$ ages, combined with $\mathrm{Sm}-\mathrm{Nd}$ and, more recently, $\mathrm{Lu}-\mathrm{Hf}$ isotopic data, helped to increase our understanding of the tectonic evolution of the Brasília Belt. Major breakthroughs are:

- The Goiás Magmatic Arc is a composite arc terrain made of magmatic arcs of different ages and nature; its older component, formed by calc-alkaline rocks generated in intraoceanic island arcs, was followed by two other episodes of arc activity, possibly in a active continental margin setting; the three main peaks of arc magmatism are shown in Figure 7.

- The arc system in central Brazil is more extense than what envisaged in previous models, extending for at least 4,000 km accross central and northeastern Brazil and into Africa.

- The different stratigraphic units of the supracrustal sequences of the belt have distinct ages and tectonic significance:

1. the Paranoá and Canastra groups most likely represent passive margin sequences deposited along the continental shelf of the São Francisco Craton,

2. the Araxá and Ibiá groups are syn-orogenic deposits (back- or fore-arc deposits, younger than ca. $650 \mathrm{Ma})$, and 
3. the Bambuí Group, which is as young as 550 $540 \mathrm{Ma}$ possibly, represents, at least in part, the foreland basin of the orogen.

- The three large mafic-ultramafic complexes are representative of two rift systems, one at ca. $1.25 \mathrm{Ga}$, and the younger at. ca. $0.79 \mathrm{Ga}$. These ages are not common in the South America platform, and, therefore, these complexes (Barro Alto, Niquelândia and Canabrava Complexes) and associated volcano-sedimentary sequences
(Juscelândia, Indaianópolis and Palmeirópolis, respectively) are interpreted as allochthonous units in the Brasília Belt evolution.

- The high grade terrains of the Uruaçu and Anápolis-Itauçu complexes are neoproterozoic in age and represent the metamorphic cores of the orogen; the contemporaneity between the UHT metamorphism and emplacement of abundant mafic-ultramafic intrusions is noteworthy in the Anápolis-Itauçu Complex in the central part of the orogen.

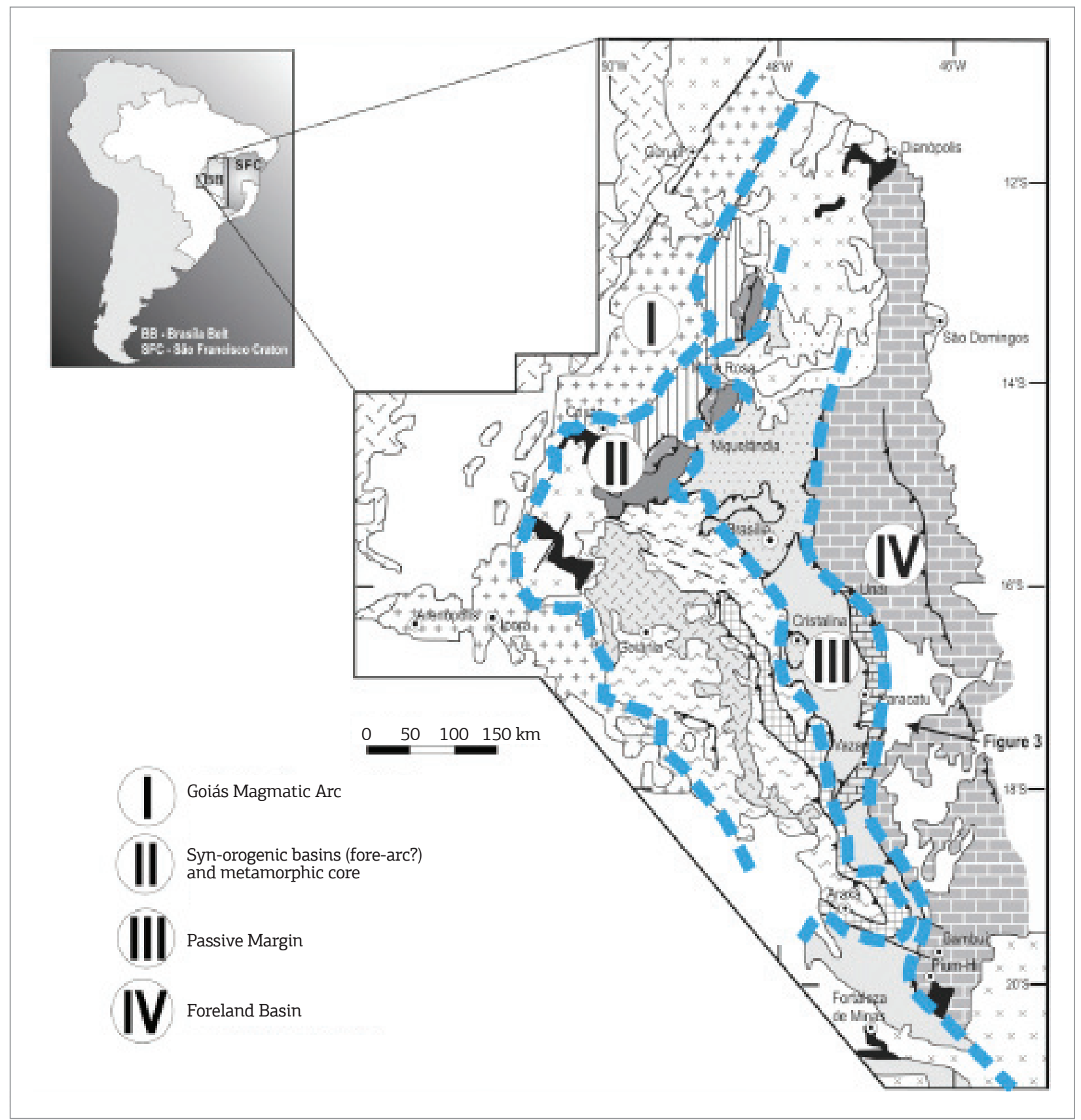

Figure 8. The different compartments of the Brasília Belt. 
- The data discussed here allow, at this stage, the recognition of first order tectonic compartments of the Brasília orogen as indicated in Figure 8. The orogen records, therefore, most of the features which normally results from the closure of a wide ocean, the Goiás-Pharusian ocean, over the long period of time, between ca. 900 and $600 \mathrm{Ma}$.

\section{ACKNOWLEDGEMENTS}

Continuous support provided by CNPq, CAPES, FINEP and PETROBRAS research grants is acknowledged and has been essential to keep field and laboratory work of the research group at the Geochronology Laboratory of the Universidade de Brasília.

\section{REFERENCES}

Almeida F.F.M., Hasui Y., Fuck R.A. 1981. Brazilian structural provinces: an introduction. Earth Sciences Review, 17:1-9.

Arantes D., Osborne G.A., Buck P.S., Porto C.G. 1991. The Mara Rosa volcano-sedimentary sequence and associated gold mineralization. In: Ladeira E.A (ed.). Brazil Gold'91. Rotterdam, Balkena, p. 221-229.

Araujo C.E.G., Rubatto D., Hermann J., Cordani U.G., Caby R., Basei M.A.S. 2014. Ediacaran 2,500-km-long synchronous deep continental subduction in the West Gondwana Orogen. Nature Communications, 5:5198

Babinski M., Vieira L.C., Trindade R.I.F. 2007. Direct dating of the Sete Lagoas cap carbonate (Bambuí Group, Brazil) and implications for the Neoproterozoic glacial events. Terra Nova, 19:401-406.

Baldwin J.A., Powell R., Brown M., Moraes R., Fuck R.A. 2005. Modelling of mineral equilibria in ultrahigh-temperature metamorphic rocks from the Anápolis-Itauçu Complex, central Brazil. Journal of Metamorphic Geology, 23:511-531.

Berger J., Caby R., Liégeois J-P, Mercier J.C.C, Demaiffe D. 2011. Deep inside a neoproterozoic intra-oceanic arc: growth, differentiation and exhumation of the Amalaoulaou Complex (Gourma, Mali). Contributions to Mineralogy and Petrology,162:773-796.

Botelho N.F., Dantas E.L., Laux J.H., Junges S.L. 2006. The Pleoproterozoic peraluminous Aurumina granite suite, Goiás and Tocantins: whole-rock geochemistry and Sm-Nd isotopic constraints. In: The Paleoproterozoic Record of the São Francisco Craton, Brazil. IGCP 509, Brazil, pp. 9-21.

Brito Neves B.B. \& Fuck R.A. 2014. Basement of the South american platform: Half Laurentian (N_NW) + Half Gondwanan. Precambrian Research, 244:75-86

Brito Neves B.B., Fuck R.A., Pimentel M.M. 2014. The Brasiliano collage in South America: a review. Brazilian Journal of Geology, 44(3):493-518.

Brod J.A. \& Jost H. 1991. Características estruturais, litológicas e magmáticas da zona de cisalhamento dúctil do Rio Traíras, bloco do Complexo de Niquelândia, Goiás. Revista Brasileira de Geociências, 21:205-217.

Caby R. 2003. Terrane assembly and geodynamic evolution of central-western Hoggar: a synthesis. Jour. African Earth Sciences, 37:133-159.

Caby R., Renaud U-A, Pin C. 1989. Late Proterozoic arc-continent and continent-continent collision in the pan-African Trans-Saharan belt of Mali. Canadian Journal of Earth Sciences, 26:1136-1146.

Campos J.E.G., Dardenne M.A., Freitas-Silva F.H., Martins-Ferreira M.A.C. 2013. Geologia do Grupo Paranoá na porção externa da Faixa Brasília. Brazilian Journal of Geology, 43(3):461-476.

Cloud P. \& Dardenne M.A. 1973. Proterozoic age of the Bambuí Group in Brazil. Geological Society of America Bulletin, 84:1673-1676.
Cordani U.G., Pimentel M.M., Araújo C.E.G, Basei M.A.S, Fuck R.A., Girardi V.A.V. 2013a. Was there an Ediacaran Clymene Ocean in central Brazil? American Journal of Sciences, 313:517-539

Cordani U.G., Pimentel M.M., Araújo C.E.G., Fuck R.A. 2013b. The significance of the Transbrasiliano-Kandi tectonic corridor for the amalgamation of West Gondwana. Brazilian Journal of Geology, 43:583-597

Cordeiro P., Oliveira C.G., Giustina M.E.S.D., Dantas E.L., Santos R.V. 2014. The Paleoproterozoic Campinorte Arc: tectonic evolution of a central Brazil pre-Columbia orogen. Precambrian Research, 251:49-61.

Correia C.T., Sinigoi S., Girardi V.A.V., Mazzucchelli M., Tassinari C.C.G., Giovanardi T. 2012. The growth of large mafic intrusions: Comparing Niquelândia and Ivrea igneous Complexes. Lithos, 155:167-182.

Cruz E.L.C.C. \& Kuyumjian R.M. 1998. The geology and tectonic evolution of the Tocantins granite-greenstone terrane, AlmasDianópolis region, Tocantins State, central Brazil. Revista Brasileira de Geociências, 28(2):173-182

Dardenne M.A. 2000. The Brasília fold belt. In: Cordani U.G., Milani E.J., Thomaz Filho A., Campos D.A. (eds.). Tectonic Evolution of South America. 31st International Geological Congress, Rio de Janeiro, p. 231-236.

Della Giustina M.E.S., Oliveira C.G., Pimentel M.M., Melo L.V., Fuck R.A., Dantas E.L., Buhn B. 2009a. U-Pb and Sm-Nd constraints on the nature of the Campinorte Sequence and related Paleoproterozoic juvenile orthogneisses, Tocantins Province, central Brazil. Geological Society, London, Special Publications, 323:255-269

Della Giustina M.E.S., Oliveira C.G., Pimentel M.M., Buhn B. 2009b. Neoproterozoic magmatism and high-grade metamorphism in the Goiás Massif: new LAM-ICPMS U-Pb and Sm-Nd data and implications for the collisional history of the Brasília Belt. Precambrian Research, 172:67-79.

Della Giustina M.E.S., Pimentel M.M., Ferreira Filho C.F., Hollanda M.H.B.M. 2011. Dating coeval mafic magmatism and ultrahigh temperature metamorphism in the Anápolis-Itauçu Complex, Central Brazil. Lithos, 124:82-102.

Dostal J., Dupuy C., Caby R. 1994. Geochemistry of the neoproterozoic Tilemsi belt of Iforas (Mali, Sahara): a crustal section of an oceanic island arc. Precambian Research, 65:55-69.

Ferreira Filho C.F., Kamo S.L., Fuck R.A., Krogh T.E., Naldrett A.J. 1994. Zircon and rutile U-Pb geochronology of the Niquelândia layered mafic and ultramafic intrusion, Brazil: constraints for the timing of magmatism and high grade metamorphism. Precambrian Research, 68:241-255.

Ferreira Filho C.F., Moraes R.M., Fawcett A.J., Naldrett A.J. 1998. Amphibolite To Granulite Progressive Metamorphism In The Niquelandia Complex Central Brazil: Regional Tectonic Implications. Journal of South American Earth Sciences, 11:35-49. 
Ferreira Filho C.F. \& Pimentel, M.M. 2000. Sm-Nd isotope systematics and REE data of troctolites and their metamorphic equivalents of the Niquelândia Complex, central Brazil: further constraints for the timing of magmatism and metamorphism. Journal of South American Earth Sciences, 13:647-659.

Ferreira Filho C.F., Pimentel M.M., Araujo S.M., Laux J. 2010. Layered Intrusions and Volcanic Sequences in Central Brazil: Geological and Geochronological Constraints for Mesoproterozoic (1.25 Ga) and Neoproterozoic (0.79 Ga) Igneous Associations. Precambrian Research, 183:617-634.

Fischel D.P., Pimentel M.M., Fuck R.A., Armstrong R.A. 2001. U-Pb SHRIMP and Sm-Nd geochronology of the Silvânia volcanics and Jurubatuba granite: Paleoproterozoic juvenile magmatic rocks in the basement of the Brasília Belt, central Brazil. Anais da Academia Brasileira de Ciências, 73(3):1-13.

Fortes P.T.F.O., Giuliani G., Takaki T., Pimentel M.M., Teixeira W. 1995. Aspectos geoquímicos do Depósito Aurífero Mina III, greenstone belt de Crixás, Goiás. Geochimica Brasiliensis (Rio de Janeiro), Porto Alegre, IX,(1):13-31.

Guimarães E.M. 1997. Estudos de proveniência e diagênese com ênfase na caracterização dos filossilicatos dos grupos Paranoá e Bambuí, na região de Bezerra - Cabeceiras (GO). Doctorate thesis, Universidade de Brasília, Brasília, 180 pp.

Jost H., Fuck R.A., Brod J.A., Dantas E.L., Meneses P.R, Assad M.L.L., Pimentel M.M., Blum M.L.B., Silva A.M., Spigolon A.L.D., Maas M.V.R., Souza M.M., Fernadez B.P., Faulstich F.R.L., Macedo Júnior P.M., Schobbenhaus C.N., Almeida L, Silva A.A.C., Anjos C.W.D., Santos A.P.M.T., Bubenick A.N., Teixeira A.A.A., Lima B.E.M., Campos M., Barjud R.M., Carvalho D.R., Scislewski L.R., Sarli C.L., Oliveira D.P.L. 2001. Geologia de terrenos arqueanos e proterozóicos da região de Crixás-Cedrolina, Goiás. Revista Brasileira de Geociências, 31:315-328.

Jost H., Chemale Jr. F., Dussin I.A., Martins R.A. 2010. U-Pb zircon Paleoproterozoic age for the metasedimentary host rocks and gold mineralization of the Crixás greenstone belt, Goiás, Central Brazil. Ore Geology Reviews, 37:127-139.

Jost H., Chemale Jr. F., Fuck R.A., Dussin I.A. 2013. Uvá complex, the oldest orthogneisses of the Archean-Paleoproterozoic terrane of central Brazil. Journal of South American Earth Sciences, 47:201-212.

Laux J.H., Pimentel M.M., Dantas E.L., Armstrong R., Junges S.L. 2005. Two Neoproterozoic custal accretion events in the Brasília Belt, central Brazil. Journal of South American Earth Sciences, 18:183-198

Marangoni Y.R., Assumpção M., Fernandes E.P. 1995. Gravimetria no norte de Goiás, Brasil. Revista Brasileira de Geofísica, 13(3):205-219.

Marini O.J., Fuck R.A., Dardenne M.A., Danni J.C.M. 1984. Província Tocantins. Setores Central e Sudeste. In: Almeida F.F.M., Hasui Y. (eds.). O Pre-Cambriano do Brasil. Edgard Blucher, São Paulo, Brazil, pp. 205-264.

Martins M. \& Lemos V. 2007. Análise estratigráfica das seqüências neoproterozóicas da Bacia do São Francisco. Revista Brasileira de Geociências, 37:156-167.

Matteini M., Dantas E., Pimentel M.M., Alvarenga C.J.S., Dardenne M.A. 2012. U-Pb and Hf isotope study on detrital zircons from the Paranoá Group, Brasília Belt Brazil: Constraints on depositional age at Mesoproterozoic - Neoproterozoic transition and tectonomagmatic events in the São Francisco craton. Precambrian Research, 206-207:168-181.

Moraes R. \& Fuck R.A. 1994. Deformação e metamorfismo das seqüências Juscelândia e Serra da Malacacheta, Complexo Barro Alto, Goiás. Revista Brasileira de Geociências, 24:189-197.
Moraes R. \& Fuck R.A. 1996. Condições de metamorfismo e evolução das paragêneses da seqüência vulcano-sedimentar Juscelândia, Complexo Barro Alto, Goiás. In: $39{ }^{\circ}$ Congresso Brasileiro de Geologia, 1996, Salvador. Boletim de Resumos expandidos, v. 2. p. 110-112.

Moraes R. \& Fuck R.A. 2000. Ultra-high-temperature metamorphism in Central Brazil: the Barro Alto complex. Journal of Metamorphic Geology, 18:345-358

Moraes R., Brown M., Fuck R.A., Camargo M.A., Lima T.M. 2002. Characterization and P-T evolution of melt-bearing ultrahightemperature granulites: an example from the AnápolisItauçu Complex of the Brasília Fold Belt. Journal of Petroleum, 43(9):1673-1705.

Moraes R., Fuck R.A., Pimentel M.M., Gioia S.M.C.L., Figueiredo A.M. 2003. Geochemistry and Sm-Nd Isotopic Characteristics of bimodal Volcanic rocks of Juscelândia, Goiás, Brazil: Mesoproterozoic transition from continental rift to ocean basin. Precambrian Research, 125(3-4):317-336

Moraes R., Fuck R.A., Pimentel M.M., Gioia S.M.C.L., Hollanda M.H.B.M., Armstrong R. 2006. The bimodal rift-related Juscelândia volcano-sedimentary Sequence in Central Brazil: Mesoproterozoic extension and Neoproterozoic metamorphism. Journal of South American Earth Sciences, 20:287-301.

Parenti-Couto J.G., Cordani U.G., Kawashita K., Iyer S.S., Moraes N.M.P. 1981. Considerações sobre a idade do Grupo Bambui, com base em análises isotópicas de $\mathrm{Sr}$ e $\mathrm{Pb}$. Revista Brasileira de Geociências, 11(1):5-16.

Paula-Santos G.M., Babinski M., Kuchenbecker M., Caetano-Filho S., Trindade R.I., Pedrosa-Soares A.C. 2014. New evidence of an Ediacaran age for the Bambuí Group in southern São Francisco craton (eastern Brazil) from zircon U-Pb data and isotope chemostratigraphy. Gondwana Research, in press.

Pimentel M.M., Heaman L., Fuck R.A. 1991. Zircon and shpene Pb-U geochronology of Upper Proterozoic volcanic-arc rock units from southwestern Goiás, central Brazil. Journal of South

American Earth Sciences, 4:329-339.

Pimentel M.M. \& Fuck R.A. 1992. Neoproterozoic crustal accretion in central Brazil. Geology, 20:375-379.

Pimentel M.M., Fuck R.A., Alvarenga C.J.S. 1996. Post Brasiliano (Pan-African) high-K granitic magmatism in Central Brazil: the role of the Late Precambrian-early Paleozoic extension. Precambrian Research, 80:217-38

Pimentel M.M., Whitehouse M.J., Viana M.G., Fuck R.A., Machado N. 1997. The Mara Rosa Arc in the Tocantins Province: further evidence for Neoproterozoic crustal accretion in Central Brazil. Precambrian Research, 81:299-310.

Pimentel M.M., Fuck R.A., Jost H., Ferreira Filho C.F., Araújo S.M. 2000a. The basement of the Brasília Fold Belt and the Goiás Magmatic Arc. In: Cordani U.G., Milani E.J., Thomaz Filho A., Campos D.A. (eds.). Tectonic Evolution of South America. 31st International Geological Congress, Rio de Janeiro, p. 195-229.

Pimentel M.M., Fuck R.A., Gioia D.M.C.L. 2000b. The Neoproterozoic Goiás Magmatic Arc, Central Brazil: A review and new Sm-Nd isotopic data. Revista Brasileira de Geociências, 30(1):35-39.

Pimentel M.M. Dardenne M.A., Fuck R.A. Viana M.G., Junges S.L. Seer H.J., Fischel D.P. 2001. Nd isotopes and the provenance of sediments of the Neoproterozoic Brasília Belt, central Brazil. Journal of South American Earth Sciences, 14:571-585.

Pimentel M.M., Jost H., Fuck R.A., Armstrong R.A., Dantas E.L., Potrel A. 2003. Neoproterozoic anatexis of 2.9 Ga old granitoids in the Goiás-Crixás block, Central Brazil: evidence from new SHRIMP U-Pb data and SmeNd isotopes. Geologia USP, Série Científica, 3:1-12. 
Pimentel M.M., Ferreira Filho C.F., Armstrong R.A. 2004. SHRIMP $\mathrm{U}-\mathrm{Pb}$ and $\mathrm{Sm}-\mathrm{Nd}$ ages of the Niquelândia layered complex: Meso$(1.25 \mathrm{Ga})$ and Neoproterozoic $(0.79 \mathrm{Ga})$ extensional events in central Brazil. Precambrian Research, 132:133-153.

Pimentel M.M., Ferreira Filho C.F., Armele A. 2006. Neoproterozoic age of the Niquelândia Complex, central Brazil: Further ID-TIMS $\mathrm{U}-\mathrm{Pb}$ and $\mathrm{Sm}-\mathrm{Nd}$ isotopic evidence. Journal of South American Earth Sciences, 21:228-238.

Pimentel M.M., Rodrigues J.B., DellaGiustina M.E.S., Junges S.L., Matteini M. 2011. The Tectonic Evolution of the Neoproterozoic Brasília Belt, Central Brazil, based on SHRIMP and LA-ICPMS U-Pb sedimentary provenance data: a review. Journal of South America Earth Sciences, 31:345-357.

Piuzana D., Pimentel M.M., Fuck R.A., Armstrong R. 2003a. SHRIMP $\mathrm{U}-\mathrm{Pb}$ and $\mathrm{Sm}-\mathrm{Nd}$ data for the Araxá Group and associated rocks: Constraints for the age of sedimentation and geodynamic context of the southern Brasília Belt, central Brazil. Precambrian Research, 125:139-160.

Piuzana D., Pimentel M.M., Fuck R.A., Armstrong R.A. 2003b. Neoproterozoic granulite facies metamorphism and coeval granitic magmatism in the Brasilia Belt, Central Brazil: regional implications of new SHRIMP U-Pb and Sm-Nd data. Precambrian Research, 125:245-273.

Queiroz C.L., Jost H., Silva L.C., McNaughton N.J. 2008. U-Pb SHRIMP and Sm-Nd geochronology of granite-gneiss complexes and implications for the evolution of the Central Brazil Archean Terrain. Journal of South American Earth Sciences, 26:100-124.

Rodrigues J.B. 2008. Proveniência de sedimentos dos grupos Canastra, Ibiá, Vazante e Bambuí - Um estudo de zircões detríticos e Idades Modelo Sm-Nd. Doctorate thesis, Universidade de Brasília, unpublished.

Rodrigues J.B., Pimentel M.M., Dardenne M.A., Armstrong R.A. 2010. Age, provenance and tectonic setting of the Canastra and Ibiá groups (Brasília belt, Brazil): implications for the age of a Neoproterozoic glacial event in central Brazil. Journal of South American Earth Sciences, 29:512-521.

Rodrigues J.B., Pimentel M.M., Buhn B., Matteini M., Dardenne M.A., Alvarenga C.J.S., Armstrong R.A. 2012. Provenance of the Vazante Group: New U-Pb, Sm-Nd, Lu-Hf isotopic data an implications for the tectonic evolution of the Neoproterozoic Brasília Belt. Gondwana Research, 21:439-450.
Santos R.V., Alvarenga C.J.S., Dardenne M.A., Sial A.N., Ferreira V.P. 2000. Carbon and oxygen isotope profiles across MesoNeoproterozoic limestones from central Brazil: Bambuí and Paranoá groups. Precambrian Research, 104:107-122.

Santos R.V., Oliveira C.G., Souza V.H.V., Carvalho M.J., Andrade T.V., Souza H.G.A. 2008. Correlação isotópica baseada em isótopos de Carbono entre os greenstone belts de Goiás. In: Brazilian Geologic Congress, Curitiba, 44, p. 52. Abstract Volume.

Seer H.J. 1999. Evolução Tectônica dos Grupos Araxá, Canastra e Ibiá na Sinforma de Araxá, MG. Doctorate Thesis, Universidade de Brasília, Brasília, 230 pp.

Strieder A.J. \& Nilson A.A. 1992. Mélange ofiolítica nos metassedimentos do Grupo Araxá de Abadiânia (GO) e implicações tectônicas regionais. Revista Brasileira de Geociências, 22:204-215.

Tassinari C.C.G., Jost H., Santos J.C., Nutman A.P., Bennell M.R. 2006. Pb and Nd isotope signatures and SHRIMP U-Pb geochronlogical evidence of Peloproterozoic age for Mina III gold mineralizations, Crixás District, Central Brazil. In: V South American Symposium on Isotope Geology, pp. 615e617. Pucon, Chile, Extended Abstracts, CD-rom.

Thomaz Filho A., Kawashita K., Cordani U.G., 1998. A origem do Grupo Bambuí no contexto da evolução geotectônica e de idades radiométricas. Anais da Academia Brasileira de Ciências, 70:527e548.

Valeriano C.M., Machado N., Simonetti A., Valladares C.S., Seer H.J., Simões L.S.A. 2004. U-Pb geochronology of the southern Brasília belt (SE-Brazil): sedimentary provenance, Neoproterozoic orogeny and assembly of West Gondwana. Precambrian Research, 130:27-55.

Valeriano C.M. \& Simões L.S.A. 1997. Geochemistry of Proterozoic mafic rocks from the Passos nappe (Minas Gerais, Brazil): tectonic implications to the evolution of the southern Brasilia belt. Revista Brasileira de Geociências, 27:99-110.

Valeriano C.M., Pimentel M.M., Heilbron M., Almeida J.C.H., Trouw R.A. 2008. Tectonic evolution of the Brasília Belt, Central Brazil, and early assembly of Godwana. Geological Society, London, Special Publications, 294:197-210.

Warren L.V., Quaglio F., Riccomini C., Simões M.G., Poiré D.G., Strikis N.M., Anelli L.E., Strikis P.C. 2014. The puzzle assembled: Ediacaran guide fossil Cloudina reveals an old proto-Gondwana seaway. Geology, 42:391-394.

Available at www.sbgeo.org.br 